Oksana Zhylinska,

D.Sc., Professor, Taras Shevchenko National University of Kyiv, Ukraine

(iD) ORCID ID, 0000-0001-8366-0474

email: zhylinska@ukr.net

Iryna Novikova,

Ph.D., Taras Shevchenko National University of Kyiv, Ukraine

(iD) ORCID ID, 0000-0003-0440-2616

email: ie_novikova@meta.ua

Alla Stepanova,

Ph.D., Associate Professor, Taras Shevchenko National University of Kyiv, Ukraine

(iD) ORCID ID, 0000-0002-1711-7948

email: ra_a@ukr.net

Alona Vikulova,

Ph.D., Taras Shevchenko National University of Kyiv, Ukraine

ORCID ID, 0000-0001-8506-0966

email: vikulova.alyona@gmail.com

Correspondence author: hylinska@ukr.net

\title{
ASSESSMENT METHODS OF INTELLECTUAL PRODUCT IN RESEARCH UNIVERSITIES
}

Abstract. This paper summarizes the arguments and counterarguments within the scientific debate over how to find the best methodology for valuing the intellectual products of research universities. The main purpose of the research is to propose a methodology for evaluating the product of intellectual labour in research universities. The systematization of literary sources and approaches to solving the problem of valuation of intellectual property has shown that, despite the considerable amount of scientific work on the valuation of intellectual property objects, there is no methodology for their evaluation in research universities. This problem is actualized at the stage of transformation of an intellectual product into a full-fledged type of economic activity. This study sheds light on the basic basics of the proposed methodology for determining the technical and economic utility of an intellectual product. The author's methodology improves the classification of the intellectual property valuation and the basic concepts used in carrying out the valuation, the types of values, methodological approaches to the valuation and calculation of the intellectual property, the baseline information requirements, the evaluation procedure and the calculations. However, particular attention is paid to the main provisions for evaluating the university's intellectual performance. The developed methodological recommendations will be useful to experts in cost estimation in intellectual property, in rendering independent valuation services, in carrying out internal valuation and in experts in carrying out valuation assessment. The methodological basis of the study is a scientific and practical understanding of the achievements of foreign scientists in the field of intellectual capital theory and analysis of Ukrainian legislation in the field of intellectual property. Methodological tools of the study were methods of economic-mathematical and logical-structural modelling. Research universities are selected as the research object because they are the core of the creation of intelligent and innovative products and the main driver of scientific and technological progress in the country and the world. The research empirically confirms and theoretically proves that the developed methodology for the intellectual activity evaluation of research universities is the basis for organizing and implementing the process of determining the value of objects of intellectual property of the institution.

Keywords: intellectual property object, intellectual product, intellectual activity, research universities, methods of valuation of intellectual property objects.

Cite as: Zhylinska, O., Novikova, I., Stepanova, A., \& Vikulova, A. (2020). Assessment Methods of Intellectual Product in Research Universities. Marketing and Management of Innovations, 3, 32-44. http://doi.org/10.21272/mmi.2020.3-03 
O., Zhylinska, l., Novikova, A., Stepanova, A., Vikulova. Assessment Methods of Intellectual Product in Research Universities.

Introduction. Research universities have long been recognized as the leading centres of research and know-how. The primary purpose of generating the results of their intellectual activity is to form a portfolio of intellectual property (IP) assets. However, the vast majority of annual discoveries never leave the walls of their maternal institutions. Given that the pace of accelerating global innovation development is steadily increasing, both for universities and for society as a whole, it is threatening a serious loss of intellectual capital. In theory, intellectual property can be bought, sold, exchanged or donated like any other property. In practice, the biggest obstacle to these operations is the intangible nature of the intellectual property. Therefore, it cannot be determined or identified by its physical parameters. At the same time, it must have a specific value expression when carrying out the purchase/sale transaction. For the practical application of the invention, it should be unique and useful. It must undergo a legal clearance (protection) and evaluation procedure. Attempts to evaluate new technologies are similar to the question, what is the length of a long rope? Obviously, there can be no unpopular assessment of new technology. Its value to users will vary depending on the degree of demand in the relevant market. Regardless of whether the buyer or seller makes the assessment, it can be both subjective and objective. However, the lack of a fair, impartial, practical method of valuing the intellectual property is a major problem faced by transferring technology transfer offices of research universities when attempting to commercialize inventions created by academics, graduate students, or students of these universities. To address this problem, it is offered the tools that can help universities evaluate their intellectual work outcomes in the first place, namely an intellectual product created in the context of the performance of functional responsibilities and terms of employment by scientists.

Literature Review. The question of evaluating intellectual property attracts the attention of many scientists and practitioners of the intellectual property industry. The literature on this topic is extensive and summarised in the works of many scientists. Chiesa et al. (2008), well noted, that the most traditional diffused valuation methods are classified into three groups: cost, market and income methods, which is highlighted in many works, such as Anson, Hoffman and Smith; Khouryet, Mardet, Mard and other. However, there are studies that differ from the traditional approach to the evaluation of the intellectual property. At the same time, Kamiyama et al. (2006) divided methods for evaluating intellectual property into quantitative and qualitative groups. Trochim (2006) noted: «The quantitative valuation would answer the question «how much». While a qualitative approach would be seen as an investigation of the why and how of decision making related to the use of the $\mid P_{\Perp} »$.

In the new book «Intellectual property: valuation, exploitation, and infringement damages» (Parr \& Smith, 2018) the authors described basic approaches and methods for evaluating the intellectual property and the practices of commercialization. In addition to traditional methods, the author highlights the buildup method, which similar to CAPM calculation, $5 \%$ of sales method ant the analytical approach.

Wilson, B.S. (2012) noted that valuations of intellectual property using the income- or option-based approaches is difficult and not always accurate, in large part because predicting the future is difficult and inexact. The author suggested a method for ongoing retrospective valuations of intellectual property to set royalty rates based on the actual performance of the intellectual property in the marketplace, uses measurable variables that indicate the value of an IP directly to a licensee over time.

Susan Chaplinsky (2002), Professor of Business Administration with the assistance of Graham Payne by the University of Virginia Darden School Foundation, Charlottesville, VA in addition to traditional approaches isolated the following methods: Discounted Cash Flow (DCF) Method, which determined the value of the IP by computing the present value of cash flows, attributable to that piece of IP, over the useful life of the asset; Venture Capital Method, Market Comparables, Historic Cost, Replication Cost and Replacement Cost.

Cowell \& Reed (2017) suggested that the process valuation intellectual property for commercialization at the university will be effective if the business plan for technology transfer will be created with the cooperation of inventors and representatives of the business school. 
O., Zhylinska, l., Novikova, A., Stepanova, A., Vikulova. Assessment Methods of Intellectual Product in Research Universities.

Lagrost, Martin, Dubois \& Quazzotti (2010) and Kamiyama et al. (2006), shared valuation of intellectual property into two groups: methods based on a quantitative approach and Methods based on a qualitative approach. The first group includes Cost-based method, Market-based method, the Income-based method, the Excess Profit method, the Relief-from-Royalty method, the Real Options method and other. But the author noted that the choice of which method to use is still difficult and unclear. Methods based on a qualitative approach include the «Brand Equity Ten» method, developed by Aaker (1996), the Value Indicators approach, which analysis IP information, based on the calculation of the IP Quotient (IPQw) Score. This method, according to the author, is easy to understand. Sun \& Ma (2013) suggested an improved income discount model. The model divided evaluation process into two steps: first, adding the GM $(1,1)$ dynamic forecast the discount rate into the income approach discount formula, obtaining the initial evaluation value; second - rectified the deviation using fuzzy synthetic evaluation model, obtaining the final evaluation value.

Xiao-yang \& Chang-xin (2013) suggested put forwards the calculation model based on the Real Options to measure the value of Intellectual Property, to provide a practical reference for intellectual property pricing. The evaluation of the intelligent product includes future benefits for the developer. It is the issue of Savva \& Taneri (2015), where the issue of fairness of payments, namely, royalties, is rationally justified.

As noted in the work of Dr Karl-Heinz Leitner (2004) that Universities are producers of knowledge, the qualitative results of which are embodied in the products of intellectual capital by researchers. In this case, the intellectual capital is considered to be a tool for reorganizing Austrian universities. The author proposed a concept for the international discussion of new management and evaluation systems for universities. Given the role of the intellectual product in the development of the university, it is worth noting the importance of sound process management and the implementation of a strategic vision for the possibility of obtaining economic effects for research universities. It is the issue of Klofsten et al. (2019), which highlights the vision of the university through the prism of future challenges in the social and economic planes.

Despite a large number of scientific works on the evaluation of the intellectual property, there is currently no methodology for their evaluation in research universities. This problem is actualized at the stage of transformation of the intellectual product into a full-fledged type of economic activity.

Methodology and research methods. It is necessary to develop an optimal methodology for the value evaluation of intellectual products of universities, because of continuing scientific debate on the probable areas of valuation of products of intellectual activity of the scientific community and relying on research by scientists in the field of intellectual capital, considering the analysis of Ukrainian legislation in the field of intellectual property.

This study is aimed at modelling a practical methodology for evaluating the results of intellectual activity in research universities.

The basis for achieving the research goal is logical-structural modelling and economic-mathematical modelling. Herewith, logical-structural modelling allowed systematize the approaches to the evaluation of the intellectual property, development of algorithms for evaluating intellectual products in research universities). In turn, economic-mathematical modelling provided the development of mechanisms for evaluating intellectual products in research universities.

Results. In today's economic transformation for several intellectual property objects, such as knowhow, trademark, the image of the enterprise, a strictly justified cost estimate is difficult. Problems arise due to the lack of objective information about the state of the market in the relevant market segments, in predicting the competitiveness of the object of assessment and modelling its life cycle. In doing so, the necessary calculations are made based on actual practically implemented programs and plans, and not through hypothetical programs for the use of a specific intellectual property object (IP). The complexity of evaluating IP is due, first of all, to the difficulty of quantifying the results of the commercial use of an object 

Universities.

at one stage or another of development, industrial development or use, due to the influence of many, sometimes multifaceted, factors. Therefore, it is extremely difficult to develop a universal methodology for assessing IP. It is important to note the main well-known factors of influence, which are, if not decisive when selecting the appropriate methodology for the assessment of IP (Figure 1).

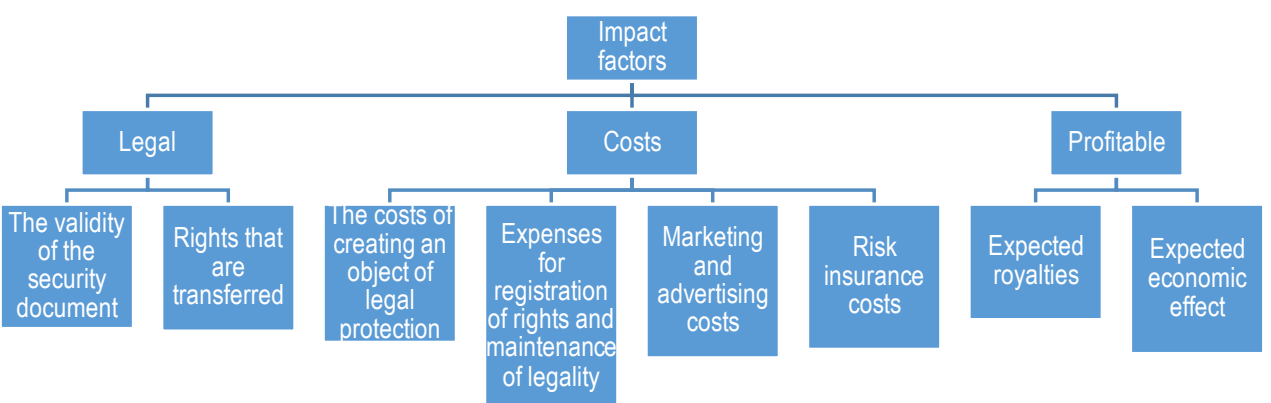

Figure 1. Key factors affecting the cost of IP

Sources: systematized by the authors based on (Fisher, 1987).

According to practice, out of 100 industrial property protection objects (that is, those for which the corresponding patents or certificates have been obtained), only two or three, when used commercially, are truly valuable and generate high profits, and only ten of them allow to cover the cost of their development. The rest are unprofitable.

We propose to detail the list of factors influencing the formation of the value of the IP. So this is:

- the price of an intellectual product depends more on the cost of reproducing the human capital involved in its creation since the decisive factor for consumer choice is the uniqueness of the commodity;

- in the context of a market economy, the demand for intellectual goods is dependent on the demand for traditional goods. Herewith, the dependence is the opposite: with the ageing of equipment, there is an objective fall in demand for it, with a steady increase in the demand for innovations capable of producing the same products at less cost. , and therefore the cost of the intellectual product itself decreases;

- the supply of intellectual goods and services depends on the demand for these products, cost of resources for their production, and openness of input information and the price of it;

- goods that have the status of social novelty benefit not only individual consumers but also society as a whole: the market, by virtue of its inherent economic nature, takes into account only the demand of the former, ignoring the demand of the latter as a whole, which leads to a restriction of production of this type of goods;

- it is advisable to take into account the stage of development and industrial development of IP; costs for the production and sale of the intellectual product.

Currently, due to the relatively short periods of the presence of new commercially attractive intellectual products in the innovation market, the decision to set the price of know-how is made in the absence of objective information on the cost-effectiveness of the use of such goods in production or management processes, which increases the risk of the intention to enter into an agreement on the purchase/sale of such goods between the university and a potential client (firm). It is precise because of the high risks in the realm of production and implementation of economic innovation that it is difficult to obtain funding for a brand new, breakthrough project from existing financial and investment institutes or departments with state authorities responsible for it. Thus, the Ministry of Education and Science of Ukraine resolves on the financing of scientific projects and scientific and technical developments after the procedure of announcement and competition between teams of scientists of universities and institutions of higher 

Universities.

education of state ownership. This competition involves the preparation of a team of project researchers, which is evaluated by an expert commission of the Ministry of Education and Science of Ukraine based on three main blocks:

1. Meaningful metrics, including information about:

- the relevance of the problem and its novelty, its relevance to economic and social needs, its importance for national security and defence, and people's lives;

- practical value and competitiveness of the obtained scientific-applied results in the world market, the possibility of introduction abroad based on market research, etc.

2. Developments and experience of the project application authors on the subject of the project for the previous 5 years, namely:

- h-index of the project leader and authors according to the database Scopus or Web of Science;

- the number of papers in journals included in scientific-metric databases Web of Science, Scopus;

- the number of papers published in journals that are included in the list of professional publications of Ukraine and have ISSN and in foreign journals;

- number of monographs or sections of monographs, including those published in foreign editions in the languages of the countries that are members of the Organization for Economic Cooperation and Development (OECD), and/or the official languages of the European Union;

- the number of security documents received (patents, certificates of copyright registration) for objects of intellectual property rights;

- the number of individual and collective grants financed by the State Budget of Ukraine and/or foreign organizations, etc.

3. Quantitative indicators of expected results (articles, monographs, security documents, defences of candidates and/or PhDs, etc.).

As a result, there is a vicious circle: for a project to be supported, it is necessary to have previous serious research work on the presented topic, which is impossible in the case of a completely new project.

The Ministry of Economic Development's Invention Support Fund, administered by the State Innovative Investment Credit Facility, also supports valuable ideas through the competitive selection of applicants. In theory, any person or business entity who has shown an interest in participating in the competition may participate. The project application is designed to describe the market approach proposed by the author(s) of know-how. Moreover, it should contain information about the essence of the idea, its difference from existing analogues, the target audience it can cover, marketing and competitive advantages, as well as the form of the business model and prepared competitive analysis. However, in practice, this fund supports economically viable projects where ready-made prototypes, working models or prototypes are presented, and it is this part of the intellectual work that is most risky and cost-intensive. Despite the small percentage of enthusiasts, it turns out that only a university that has the proper research infrastructure can provide the initial research process. The costs of this process and cost associated with the creating intellectual product, are usually the basis for the evaluation of the intellectual product of the scientist(s). This approach to evaluation is called costly. The standards used in carrying out such an assessment are described in the professional, scientific literature and are defined in Ukraine in the relevant legislative act.

The use of the outgoing cost method makes it possible to reflect the minimum (guaranteed) value of the object. Although the theoretical calculation of this method is quite simple, its application does not give an accurate estimate in practice, since some of the costs are often not fixed or lost. Definitely, the practice of movie evaluation has shown that the cost of similar films may be appropriate. Still, it is not possible to replace one movie with another, since the rental or sales revenue may be disproportionately different. Therefore, the valuating the intellectual product can be determined by the use of other methods of valuation, such as profit and comparative. However, when applying the income approach to valuation, 

Universities.

there may be severe difficulties in determining directly the portion of the profit derived from the use of any intangible asset, it is casual, i.e. it is applied to each object individually. When evaluating the cost of IP using a comparative approach, information is used on valuation objects and analogues. However, applying a comparative approach to intellectual property valuation is complex. Herewith, in some cases, it is inefficient process due to the lack of objective market data on such agreements with intellectual property entities, since it is difficult to find an adequate comparator for an individually assessed intellectual product. The same information on transactions with intellectual property objects is usually closed (Table 1).

Table 1. Advantages and disadvantages of the main known approaches to the evaluation of the intellectual property

\begin{tabular}{|c|c|c|}
\hline Approach and its essence & Advantages & Disadvantages \\
\hline $\begin{array}{l}\text { The income approach is } \\
\text { based on the application of } \\
\text { valuation procedures for the } \\
\text { transfer of expected income } \\
\text { to the value of the valuation } \\
\text { object }\end{array}$ & $\begin{array}{l}\text { the price corresponds to the market value of } \\
\text { the object; the assessment does not require } \\
\text { high costs }\end{array}$ & $\begin{array}{l}\text { requires a sufficiently accurate } \\
\text { forecast of the development of the } \\
\text { market, which is the object of } \\
\text { assessment, which is expert, and } \\
\text { therefore sufficiently subjective, } \\
\text { inaccurate information, and often } \\
\text { quite expensive }\end{array}$ \\
\hline $\begin{array}{l}\text { The cost approach is based } \\
\text { on determining the cost } \\
\text { required to reproduce or } \\
\text { replace the valuation entity. }\end{array}$ & $\begin{array}{l}\text { gives objective results when it is possible to } \\
\text { accurately estimate the magnitude of the } \\
\text { costs of creating a certain intellectual } \\
\text { property subject to a relative balance of } \\
\text { supply and demand in the innovation } \\
\text { market; for valuation, it is advisable to use } \\
\text { intangible assets that are not involved in the } \\
\text { formation of future profits and are not } \\
\text { currently profitable }\end{array}$ & $\begin{array}{l}\text { the price and market value of the } \\
\text { item being valued are different, } \\
\text { they will only match if the market is } \\
\text { balanced }\end{array}$ \\
\hline $\begin{array}{l}\text { The comparative (or market) } \\
\text { approach is applied in case } \\
\text { of sufficient information on } \\
\text { such objects' market prices } \\
\text { and terms of contracts for } \\
\text { the disposal of property } \\
\text { rights for such objects. }\end{array}$ & $\begin{array}{l}\text { It is based on market data and reflects the } \\
\text { practices that exist between buyers and } \\
\text { sellers }\end{array}$ & $\begin{array}{l}\text { the difficulty in obtaining baseline } \\
\text { data for the companies being } \\
\text { compared, the need to make a } \\
\text { number of adjustments, based on } \\
\text { past trends and not taking into } \\
\text { account future-benefits }\end{array}$ \\
\hline
\end{tabular}

Sources: developed by the authors.

Therefore, there is currently no universal method for determining the value of intellectual property. However, considering the best and most effective use of intellectual property, it is advisable to evaluate the intellectual property as part of the valuation of a business.

In the context of the conducted research, in the study attention paid to the methodology of management and evaluation of university results of intellectual activity. This methodology defines the procedure for evaluating the results of intellectual activity (RIA) of a research university and evaluating the market value of intangible assets created based on RIA. It describes the sequential actions performed in managing and conducting the RIA assessment.

The RIA mechanism is the basis for organizing and implementing the process of determining the value of the intellectual property of a higher education institution engaged in research activities, including in the process of creating business associations. It was offered the following basic positions:

1. Requirements for the evaluation of RIA.

1.1.In order to place RIA on the accounting (balance sheet) of a research university, it is necessary to estimate the cost of creation or acquiring the RIA and to set a lower limit on the monetary valuation of the 
O., Zhylinska, l., Novikova, A., Stepanova, A., Vikulova. Assessment Methods of Intellectual Product in Research Universities.

RIA usage rights. Intangible assets $(\mathrm{IA})$ that meet the following conditions may be put on the budget account: lack of material (physical) structure:

- identification (separation) of other property;

- use in producing products, in performing works or provision of services or for the management needs of an institution;

- use over a long period that is, the useful life of more than 12 months, or a standard operating cycle of more than 12 months;

- prohibition of further resale of the asset;

- availability of properly documented documents confirming the existence of the asset;

- availability of properly documented documents establishing the exclusive right to an asset;

- the existence in the cases prescribed by the law of properly documented documents proving the exclusive right to an asset (patents, certificates, other security documents, etc.) or the rights to the results of scientific and technical activities protected in the commercial secrecy, including potentially patentable technical solutions and secrets of production (know-how).

1.2. The list of RIA rights that may be used to be incorporated into the authorized capital of companies under a licensing agreement is closed. It includes only inventions, utility models, industrial designs, breeding achievements, software, databases, integrated circuit topologies, and production secrets (know-how).

2. The mechanism of determining the price range of RIA.

In the process of commercialization of an intellectual product, the entities of the intellectual property market seek their benefits. Based on this, there are two opposing positions for the seller and buyer regarding their interests in the negotiations. Therefore, reasonable pricing for intelligent product will occur within a certain price range. Determining the lower boundary of the price range is the calculation of a price that should provide reimbursement for the costs of creating an intelligent product and profit from its commercialization. This cost principle of valuation of the IP reflects the position of the licensor (seller) on completion of the contract. Determination of the upper limit of the price range is calculated based on the amount of revenue that the licensee (buyer) will receive from the implementation of the invention into production. Based on the conducted theoretical and methodological analysis of the cost estimation of the $I P$, the authors present an algorithm for determining the reasonable price of an intellectual product.

In the developed algorithm for determining the reasonable price of an intellectual product, the basic step is to evaluate the technical and economic utility. The technical and economic usefulness of an intellectual product is a relative measure of its degree of efficiency and readiness for use in the production of final products, reflecting the potential value of an intellectual property object.

It was proposed to use a modified methodology that reflects the cost principle and allows to increase the reliability of the final result to calculate the lower limit of the price range of the intellectual product,. The essence of the modification is to replace the standard scale of the coefficient of scientific and technical value with the value of the coefficient of technical and economic utility by a method developed based on the method of analysis of hierarchies (Figure 2). 
O., Zhylinska, l., Novikova, A., Stepanova, A., Vikulova. Assessment Methods of Intellectual Product in Research Universities.

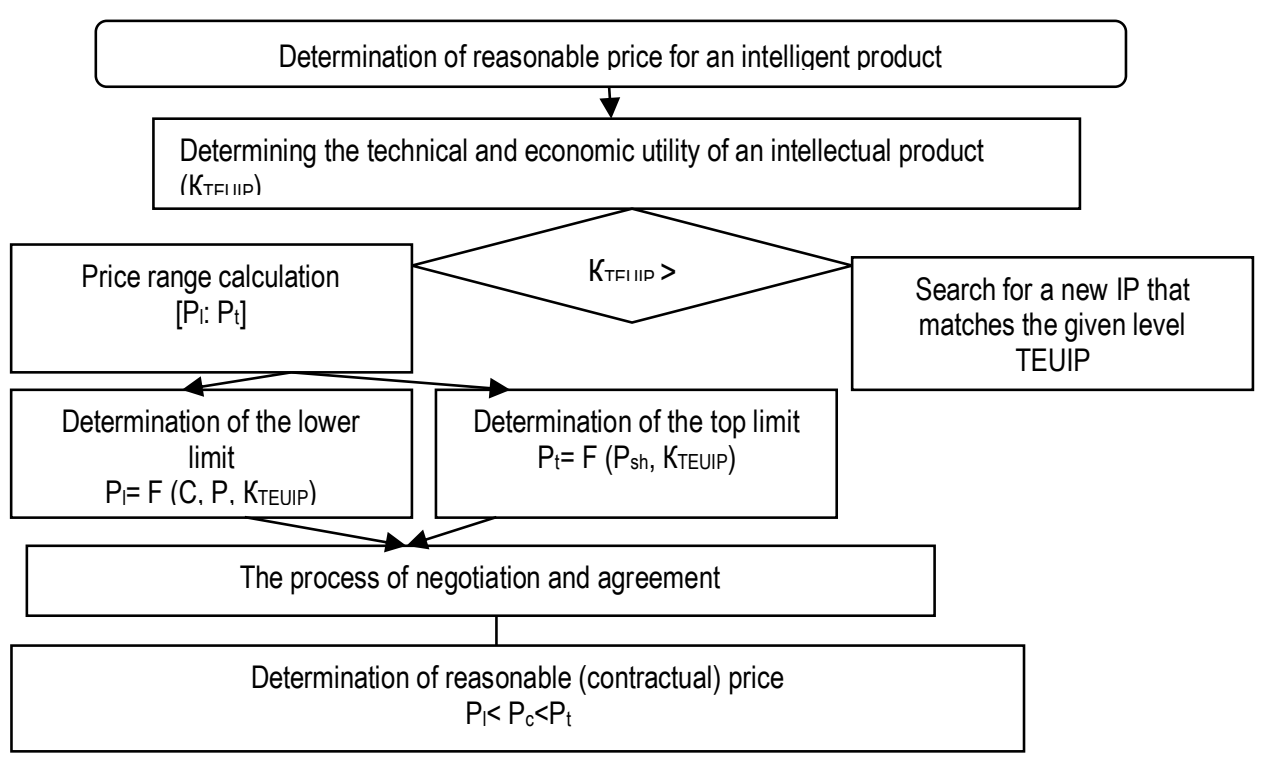

Figure 2. An algorithm for determining the reasonable price of an intellectual product

Sources: developed by the authors.

KTEUIP - coefficient of the technical and economic utility of an intellectual product; $\mathrm{KBA}_{\mathrm{TEUIP}}-$ basic assessment of the coefficient of the technical and economic utility of an intellectual product; $\mathrm{P}_{1}$ - the lower price range; $P_{t}-$ the top price range; $P_{c}$ - the contractual price; $P_{l}-$ the lower price limit of the invention; $\mathrm{P}_{\mathrm{t}}$ - the top price limit of the invention; $\mathrm{F}$ - functional and constructive features of the object of assessment; $\mathrm{C}$ - costs of the licensee to create and secure ownership of the object of the license agreement; $\mathrm{P}$ - the amount of the owner's estimated profit in monetary terms; $P_{s h}$ - profit share.

3. The mechanism of estimation of economic efficiency of RIA.

For evaluating the cost-effectiveness of RIA, a list of criteria is determined, based on which it will be possible, in the future, to decide on the appropriateness of their commercialization. Each evaluation criterion corresponds to a specific scale of change in characteristics and receives a corresponding score (Table 2).

Table 2. The mechanism for evaluating the cost-effectiveness of RIA

\begin{tabular}{|l|l|}
\hline \multicolumn{2}{|c|}{ 1. Presence of advantages over analogues } \\
\hline \multicolumn{1}{|l|}{ Features / benefits } & Preference score (in points) \\
\hline 1. Technological advantage: & 0 \\
- the conditions for creating an intellectual product are unchanged; & 1,0 \\
- conditions for creating an intelligent product are simplified; & 1,5 \\
- intellectual product creation conditions are simplified several times. & \\
\hline 2. Economic advantage: & 0 \\
- the cost of creating and marketing an intellectual product does not change; & \\
- the cost of creating and marketing an intelligent product is reduced by $30 \%$ & 1,0 \\
per year; & 2,0 \\
- costs for creating and marketing an intelligent product are reduced by $50 \%$ & \\
or more per year. & \\
\hline
\end{tabular}


O., Zhylinska, l., Novikova, A., Stepanova, A., Vikulova. Assessment Methods of Intellectual Product in Research Universities.

\section{Continued Table 2}

\begin{tabular}{|c|c|}
\hline $\begin{array}{l}\text { 3. Aesthetic advantage: } \\
\text { - improving the appearance of the intellectual product; } \\
\text { - formation of new tastes and tastes. }\end{array}$ & $\begin{array}{l}1,0 \\
2,0 \\
\end{array}$ \\
\hline $\begin{array}{l}\text { 4. Social advantage: } \\
\text { - availability of social benefits; } \\
\text { - lack of social benefits. }\end{array}$ & $\begin{array}{l}1,0 \\
0\end{array}$ \\
\hline $\begin{array}{l}\text { 5. Environmental Advantage: } \\
\text { - the environmental parameters of the intellectual product are normative and } \\
\text { stable; } \\
\text { - the environmental performance of the intellectual product is constantly } \\
\text { improving. }\end{array}$ & $\begin{array}{l}0,5 \\
1,5\end{array}$ \\
\hline \multicolumn{2}{|l|}{ 2. Market growth dynamics } \\
\hline Market growth dynamics & $\begin{array}{l}\text { Assessing the dynamics of } \\
\text { market growth (points) }\end{array}$ \\
\hline 1. There is no growth dynamics, and the market is stable. & 0 \\
\hline 2. The growth rate of intellectual product sales is 20 to $30 \%$ per year. & 4 \\
\hline 3. The growth rate of intellectual product sales is at least $100 \%$ per year. & 7 \\
\hline 4. The growth rate of intellectual product sales is over $100 \%$ per year. & 10 \\
\hline \multicolumn{2}{|l|}{ 3. Market niche } \\
\hline A qualitative characteristic of a niche market & $\begin{array}{l}\text { Market niche assessment } \\
\text { (points) }\end{array}$ \\
\hline 1. No market niche. & 0 \\
\hline 2. Market niche. & 5 \\
\hline \multicolumn{2}{|l|}{ 4. The value of the aggregate risk portfolio } \\
\hline Risk assessment & Risk assessment (points) \\
\hline 1. Implementation risks are high. & 0 \\
\hline 3. Implementation risks are negligible. & 5 \\
\hline
\end{tabular}

5. Technological and economic compatibility of the intellectual product with other products of the system

\begin{tabular}{|c|c|}
\hline Compatibility & $\begin{array}{l}\text { The value of the coefficient } \\
\text { (points) }\end{array}$ \\
\hline $\begin{array}{l}\text { 1. Technological: } \\
\text { - does not require significant changes in the system; } \\
\text { - requires replacement of individual elements of the system; } \\
\text { - requires replacement of the entire system. }\end{array}$ & $\begin{array}{l}4,0 \\
1,5 \\
0\end{array}$ \\
\hline $\begin{array}{l}\text { 2. Economic: } \\
\text { - does not require additional costs for changing the existing market } \\
\text { infrastructure; } \\
\text { - requires an increase in the cost of promoting the product by } 40-70 \% \text {; } \\
\text { - requires an increase. }\end{array}$ & $\begin{array}{l}5,0 \\
2,0 \\
0\end{array}$ \\
\hline \multicolumn{2}{|l|}{ 6. Protecting intellectual property rights } \\
\hline Degree of protection & $\begin{array}{l}\text { The value of the coefficient } \\
\text { (points) }\end{array}$ \\
\hline $\begin{array}{l}\text { 1. Security documents: } \\
\text { - availability of security documents in another country (s) } \\
\text { - availability of only national security documents (patents, licenses, } \\
\text { certificates, etc.); } \\
\text { - absence of security documents. }\end{array}$ & $\begin{array}{l}1,0 \\
0,5 \\
0\end{array}$ \\
\hline $\begin{array}{l}\text { 2. Protection against information leakage: } \\
\text { - to disclose the innovation; }\end{array}$ & 3,0 \\
\hline
\end{tabular}

Continued Table 2 
O., Zhylinska, l., Novikova, A., Stepanova, A., Vikulova. Assessment Methods of Intellectual Product in Research Universities.

\begin{tabular}{|l|l|}
\hline - security system; & 1,5 \\
- non-disclosure agreement. & 0,5 \\
\hline 3. Counterfeit protection: & \\
- production technology; & 4,0 \\
- state security authorities; & 2,5 \\
- own security service; & 1,5 \\
- lack of protection. & 0 \\
\hline
\end{tabular}

Sources: developed by the authors.

The sum of points for each criterion gives a summary estimate of the result of the intellectual activity of the intellectual product. Estimates can be used for expert judgment as a whole. Next, two main questions are addressed: how feasible is the technological feasibility of creating a novelty based on this research result and the prospect of its market implementation. If the intelligent product is intended for use in the consumer market, it receives in addition to the above points another 10; if in the market of means of production - 5 points; if it is of universal importance, then the user of the technique can estimate this indicator at 15 points. Further, based on the value of the integral indicator, the economic efficiency of RIA and their systematization is carried out, which allows making an appropriate decision regarding the intellectual product (Table 3).

Table 3. Classification of intellectual products based on their cost-effectiveness

\begin{tabular}{|c|c|c|}
\hline $\begin{array}{l}\text { The value of the } \\
\text { integral index } \\
\text { (points) }\end{array}$ & $\begin{array}{l}\text { Characteristic of economic efficiency of intellectual } \\
\text { product }\end{array}$ & Key solutions \\
\hline $3,5-11$ & $\begin{array}{l}\text { The economic effect of using this intellectual product is } \\
\text { negligible, since it has almost no advantages over } \\
\text { analogues and is not protected by any security } \\
\text { documents, the degree of risk when trying to } \\
\text { commercialize it is high. }\end{array}$ & $\begin{array}{l}\text { The feasibility of creating an } \\
\text { appropriate intellectual } \\
\text { product. }\end{array}$ \\
\hline $12-29$ & $\begin{array}{l}\text { The economic efficiency of this intellectual product is not } \\
\text { overlooked, but it is viscous, more importantly, more } \\
\text { than one market for realizing the interest in the market. } \\
\text { However, it's possible to economically be effective, as } \\
\text { it's possible to get ahead of the peers. }\end{array}$ & $\begin{array}{l}\text { It is necessary to monitor } \\
\text { market dynamics constantly. }\end{array}$ \\
\hline $30-42$ & $\begin{array}{l}\text { This intellectual product is cost-effective. It has all the } \\
\text { necessary advantages (technological, economic, social, } \\
\text { aesthetic) compared to its counterparts. The degree of } \\
\text { risk when trying to commercialize it is negligible. }\end{array}$ & $\begin{array}{l}\text { Adopting appropriate changes } \\
\text { to the existing technology } \\
\text { system and controlling costs. }\end{array}$ \\
\hline $43-55$ & $\begin{array}{l}\text { This intellectual product is economically efficient. It has } \\
\text { all the necessary advantages (technological, economic, } \\
\text { social, aesthetic, environmental) compared to its } \\
\text { counterparts. Its implementation does not require any } \\
\text { changes in the existing technological system and } \\
\text { market infrastructure. The market for this intellectual } \\
\text { product is developing at a high rate (sales are increasing } \\
\text { by more than } 100 \% \text { annually). The quality of the product } \\
\text { is confirmed and protected by various security } \\
\text { documents. }\end{array}$ & Unconditional implementation \\
\hline
\end{tabular}

Sources: developed by the authors.

4. The mechanism of accounting for IP. 
O., Zhylinska, l., Novikova, A., Stepanova, A., Vikulova. Assessment Methods of Intellectual Product in Research Universities.

According to the current legislation, namely - item 7 «Accounting Standard (Standard) 8» «Intangible Assets»: intangible assets resulting from development should be reflected in the balance sheet under the following conditions:

- if the enterprise/institution intends, technical capacity and resources to bring the intangible asset to a condition in which it is fit for sale or use;

- the possibility of obtaining future economic benefits from the sale or use of an intangible asset;

- information to accurately determine the costs associated with the development of an intangible asset.

4.1. IP objects are accepted in the budget account at their original cost.

4.2. The initial cost of an IP is the amount of actual investment in the creation of IP objects.

4.3. The actual investment for the creation of the IIP is the money spent by the research university on:

- researchers' remuneration and remuneration;

- purchase of equipment and equipment;

- purchase of materials;

- utilities;

- procurement of services of third parties (maintenance and repair of equipment or equipment; information and consulting services, advertising, etc.);

- carrying out additional works under contracts;

- business trip of researchers;

- insurance premiums;

- development of possible unsuccessful or ineffective prototypes;

- registration fees and other necessary payments made in connection with the registration of rights to the IP.

4.4. In self-assessing the RIA cost and the right to use it, a profitable approach is used in which the IA value or interest in the IA is determined by calculating the present value up to the present moment of the cost of projected future benefits.

4.5. When using a profitable approach, the peer review method (forecasting method) is used, based on the agreement of a group of experts in the management of innovative development of the university or independent evaluators.

4.6. When evaluating the cost-effectiveness of RIA, the algorithm presented in Table 1 is used.

4.7. If the research university, as a result of the creating RIA, obtains a non-exclusive right to its RIA, then this IP may be estimated below the carrying amount of the RIA.

5. Accounting mechanism for the rights to use RIA.

5.1. At a price approved by the panel of experts, RIA is put on the balance of the research university. This procedure is made out by appropriate accounting records.

5.2. An expert commission makes the decision on assessment of the right to use RIA. The useful life of the RIA is set at 10 years, and the straight-line method is used for depreciation.

The developed guidelines for intellectual product evaluation of the research universities will be useful to the performers of valuation of IIP in the provision of independent valuation services and the internal valuation; to the performers of the reliability of the valuation, the experts of the reliability of the valuation in the provision of the reliability of the expert services evaluation.

Conclusions. Thus, the conducted research makes it possible to conclude that several approaches to the valuation of the intellectual product of a research university are currently being used in business practice. However, its practical application has many disadvantages. In many cases, because of the specific nature of some organizations activities, such as research universities, it is sometimes impossible. Therefore, the existing methodology for evaluating the results of intellectual activity needs to be rethought and refined to adapt it to the current trends of the innovation market. After all, the most accurate assessment for the intellectual product will increase the investment attractiveness and competitiveness of Ukrainian research universities; attract highly professional specialists; participate in the implementation of 
O., Zhylinska, l., Novikova, A., Stepanova, A., Vikulova. Assessment Methods of Intellectual Product in Research Universities.

international projects in the field of research, which will contribute to the technological and economic uplift of our country.

The results of the study could be useful to performers of IIP valuation, in the provision of independent valuation services, in the internal valuation, as well as the performers of the valuation expertise, the valuation experts in the provision of independent valuation services.

Further scientific exploration will lie in the plane of finding optimal mechanisms for maximizing the economic and social impact of commercializing intellectual products by research universities. It is planned to take into account international experience in this matter and to analyze the current legal framework carefully.

Author Contributions: Conceptualization and supervision, O. Z. and I. N.; methodology, O. Z. and A. V.; investigation and formal analysis, A. S. and I. N.; visualization, A. S.; data curation and editing, writing, O. Z., I. N., A. S. and A. V.; writing-original draft preparation O. Z., I. N., A. S. and A. V.

\section{Referenses}

Aaker, D. (1996), Building Strong Brands, The Free Press, New York, NY [Google Scholar]

Chaplinsky, S., \& Payne, G. (2002). Methods of Intellectual Property Valuation. Darden Case No. UVA-F-1401. Retrieved from https://ssrn.com/abstract=1279326

Chiesa, V., Gilardoni, E., Manzini, R., \& Pizzurno, E. (2008). Determining The Value Of Intangible Assets-A Study And An Empirical Application. International journal of innovation and technology management, 5(01), 123-147. [Google Scholar] [CrossRef Cowell, E. W. \& Reed, J. H. (2017). Intellectual Property and Universities: A Path Forward [Point of View]. Proceedings of the IEEE, 105(7), 1195-1198. [Google Scholar] [CrossRef]

Fisher, W. (1987). Theories of Intellectual Property. [Google Scholar]

Hudzovata, O. \& Voronovska, R. (2013). Approaches and methods of evaluation of intellectual property objects. Economic analysis, 12(3), 95-99. [Google Scholar].

Industrial property in figures for 2017. State Ukrainian intellectual property institute (UKRPATENT). Retrieved from: http://www.uipv.org/i upload/file/promvlasnist-2017.pdf.

Kamiyama, S., Sheehan, J., \& Martínez, C. (2006). Valuation and Exploitation of Intellectual Property (No. 2006/5). OECD Publishing. [Google Scholar]

Klofsten, M., Fayolle, A., Guerrero, M., Mian, S., Urbano, D., \& Wright, M. (2019). The entrepreneurial university as driver for economic growth and social change-Key strategic challenges. Technological Forecasting and Social Change, 141, 149-158. [Google Scholar] [CrossRef]

Lagrost, C., Martin, D., Dubois, C., \& Quazzotti, S. (2010). Intellectual property valuation: how to approach the selection of an appropriate valuation method. Journal of Intellectual Capital. [Google Scholar] [CrossRef]

Law of Ukraine on evaluation of property, property rights and professional appraisal activity in Ukraine No. 2658-III dated January 16, 201. Retrieved from: https://zakon.rada.gov.ua/laws/show/2658-14

Leitner, K. H. (2004). Intellectual capital reporting for universities: conceptual background and application for Austrian universities. Research evaluation, 13(2), 129-140. [Google Scholar] [CrossRef]

Marty’nyuk, V.P. (2015). Intellectual Property: Textbook. Ternopil': TNEU.

On Approval of Accounting Regulations (Standard). Retrieved from: https://zakon.rada.gov.ua/laws/show/z0750-99

Order of the Ministry of Economic Development and Trade of Ukraine On Approval of the Regulation on the competitive selection of projects for state incentives for the creation and use of inventions (utility models) and industrial designs No. 1879 dated 12.12.2018. Retrieved from: https://zakon.rada.gov.ual/aws/show/z1421-18/sp:wide-'max10.

Order of the Ministry of Education and Science of Ukraine on conducting competitive selection of projects of scientific research and development №630 dated 15/06/2015. Retrieved from: https://zakon.rada.gov.ua/rada/show/v0630729-15/sp:max20/

Order of the State Property Fund of Ukraine On Approval of the Methodology for Appraisal of Intellectual Property Rights of 25.06.2008 No. 740. Retrieved from: http://zakon5.rada.gov.uallaws/show/z0726-08.

Parr, R. L. (2018). Intellectual property: valuation, exploitation, and infringement damages. John Wiley \& Sons. [Google Scholar] Resolution of the Cabinet of Ministers of Ukraine On Approval of the National Standard No.4 Evaluation of Intellectual Property Rights as of 03.10.2007 № 1185. Retrieved from: http://zakon5.rada.gov.ua/laws/show/1185-2007-\%D0\%BF.

Savva, N., \& Taneri, N. (2015). The role of equity, royalty, and fixed fees in technology licensing to university spinoffs. Management Science, 61(6), 1323-1343. [Google Scholar] [CrossRef]

Sun, B., \& Ma, W. (2013). Intellectual Property Valuation Method Based on Fuzzy Comprehensive Evaluation and Its Application. In ICCREM 2013: Construction and Operation in the Context of Sustainability (pp. 1291-1299). [Google Scholar] [CrossRef] 
O., Zhylinska, l., Novikova, A., Stepanova, A., Vikulova. Assessment Methods of Intellectual Product in Research Universities.

Trochim, W. M. (2006). The qualitative-quantitative debate. Social research methods. Retrieved from: www.socialresearchmethods.net/kb/qualdeb.php

Wilson, B.S. (2012). Retrospective valuations of intellectual property. The Journal of Technology Transer, 37(1), 124-133. [Google Scholar] [CrossRef]

Xiao-yang, Y., \& Chang-xin, X. (2013, July). A research on Intellectual Property valuation model under uncertainty. In 2013 International Conference on Management Science and Engineering 20th Annual Conference Proceedings (pp. 469-475). IEEE. [Google Scholar] [CrossRef]

Оксана Жилінська, д.е.н., професор, Київський національний університет імені Тараса Шевченка (Україна);

Ірина Новікова, к.е.н., старший дослідник, Київський національний університет імені Тараса Шевченка (Україна);

Алла Степанова, к.е.н., доцент, Київський національний університет імені Тараса Шевченка (Україна);

Альона Вікулова, к.е.н, Київський національний університет імені Тараса Шевченка (Україна).

Методика оцінювання інтелектуального продукту в дослідницьких університетах

Проведене наукове дослідження узагальнює аргументи та контраргументи в межах наукової дискусії з питання пошуку оптимальної методики вартісного оцінювання інтелектуальних продуктів дослідницьких університетів. Основною метою проведеного дослідження є розробка методики оцінювання продукту інтелектуальної праці в дослідницьких університетах. Методологічною основою роботи є науково-практичне осмислення досягнень зарубіжних вчених у галузі теорії інтелектуального капіталу та аналіз українського законодавства у сфрері інтелектуальної власності. Методичним інструментарієм проведеного дослідження стали методи економіко-математичного та логікоструктурного моделювання. Об'єктом дослідження обрані дослідницькі університети, оскільки саме вони є ядром створення інтелектуальних та інноваційних продуктів та основним рушієм науково-технічного прогресу в країні та світі. Систематизація літературних джерел та підходів до вирішення проблеми вартісного оцінювання об'єктів інтелектуальної власності засвідчила, що методика оцінювання об'єктів інтелектуальної власності в дослідницьких університетах нині відсутня. Ця проблема актуалізується на етапі трансформації інтелектуального продукту в повноцінний вид економічної діяльності. Дане дослідження висвітлює основні базові положення щодо запропонованої методики визначення техніко-економічної корисності інтелектуального продукту. У авторській методиці удосконалено класифрікацію оцінювання об'єктів інтелектуальноївласності та основні поняття, що використовуються при проведенні оцінювання, види вартостей, методичні підходи до оцінювання та розрахунку вартості об'єктів інтелектуальної власності, вимоги до вихідної інформації, порядку оцінки та проведення розрахунків. Особлива увага приділена основним положенням щодо оцінювання університетських результатів інтелектуальної діяльності. Дослідження емпірично підтверджує та теоретично доводить, що розроблена методика оцінки інтелектуальної діяльності дослідницьких університетів є основою для організації та здійснення процесу визначення вартісної оцінки об'єктів інтелектуальної власності закладу. Розроблені методичні рекомендації будуть корисними фрахівцям з вартісного оцінювання об 'єктіе інтелектуальної власності, при наданні послуг з проведення незалежного оцінювання, при проведенні внутрішнього оцінювання та фрахівцям з проведення експертизи щодо достовірності оцінювання.

Ключові слова: об'єкт інтелектуальної власності, інтелектуальний продукт, інтелектуальна діяльність, дослідницькі університети, методика оцінки об'єктів інтелектуальної власності.

Manuscript received: 11.03.2020

(C) The author(s) 2020. This article is published with open access at Sumy State University 